\title{
High Durability of a 14-Membered Hexaaza Macrocyclic Fe Complex for an Acidic Oxygen Reduction Reaction Revealed by In Situ XAS Analysis
}

Junya Ohyama, Makoto Moriya, Ryo Takahama, Kazuki Kamoi, Shin Kawashima, Ryoichi Kojima, Teruaki Hayakawa, and Yuta Nabae*

Cite This: JACS Au 2021, 1, 1798-1804

Read Online

\section{ACCESS |}

Џlll Metrics \& More

回国 Article Recommendations

Supporting Information

ABSTRACT: Nonplatinum metal (NPM) catalysts for the oxygen reduction reaction (ORR) in proton exchange membrane fuel cells (PEMFCs) have been developed; however, NPM catalysts still need to be improved in terms of both their catalytic activity and durability. To overcome these problems, an $\mathrm{Fe}$ active site contained within a more compact ligand than conventional, porphyrinic, 16-membered ring ligands, or more specifically, a hexaaza macrocyclic ligand with a 14membered ring (14MR), was developed. In this study, the durability of the Fe-14MR complex was compared to that of $\mathrm{Fe}$ phthalocyanine (FePc), which has a 16-membered ring ligand, using in situ X-ray absorption spectroscopy; demetalation of the $\mathrm{Fe}$ complexes was

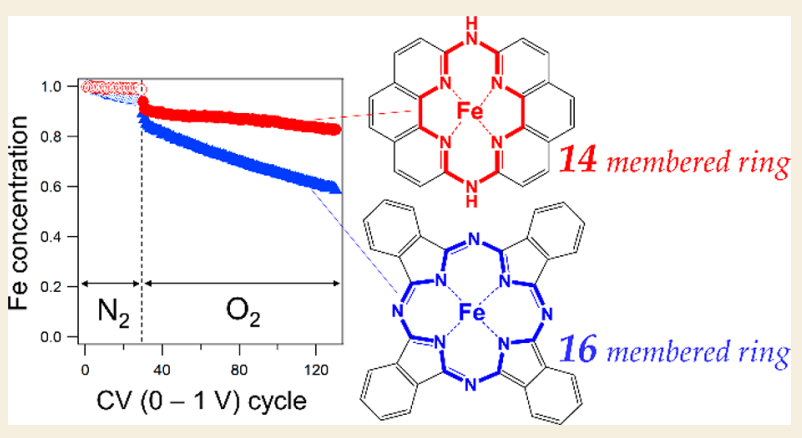
directly observed during electrochemical experiments performed under acidic ORR conditions. It was found that Fe-14MR is significantly more resistant to demetalation than FePc during the ORR.

KEYWORDS: Fuel cell, ORR, nonplatinum, Fe complex, durability, in situ XAS

\section{INTRODUCTION}

The development of nonplatinum metal (NPM) oxygen reduction reaction (ORR) catalysts with high activities and durabilities in proton exchange membrane fuel cells (PEMFCs) is challenging, as NPM catalysts are easily corroded in the acidic environment of PEMFCs. ${ }^{1-3}$ Iron catalysts prepared by pyrolyzing iron, carbon, and nitrogen $(\mathrm{Fe}-\mathrm{N}-\mathrm{C})$ precursor mixtures have been found to have relatively high activities and durabilities during the ORR in acidic media; however, their performance remains inferior to that of Pt-based catalysts. ${ }^{4-9}$ To understand and enhance the catalytic performance of $\mathrm{Fe}-\mathrm{N}-\mathrm{C}$ catalysts, the active structures of $\mathrm{Fe}-\mathrm{N}-\mathrm{C}$ catalysts have been investigated by many research groups. ${ }^{2,3,6,10-13}$ As a result, single $\mathrm{Fe}$ sites embedded in nitrogen-doped carbon materials, or more specifically, $\mathrm{FeN}_{4}$ sites, have been proposed as ORR active sites. ${ }^{6,12,13}$ However, the $\mathrm{FeN}_{4}$ sites in nonpyrolyzed $\mathrm{Fe}$ precursors or complexes, e.g., $\mathrm{Fe}$ phthalocyanine $(\mathrm{FePc}$ ) and $\mathrm{Fe}$ porphyrin, are not stable under acidic ORR conditions due to demetalation triggered by the ORR. ${ }^{14,15}$ If highly stable and active Fe macrocyclic complexes are prepared, new types of durable NPM catalysts can be developed by modifying the ligands of the catalyst to tune the electronic structure of the Fe centers and building them up into catalysts with three-dimensional architectures.
The structure performance of $\mathrm{Fe}-\mathrm{N}-\mathrm{C}$ catalysts during the ORR is of great interest, as it has been revealed that $\mathrm{Fe}-\mathrm{N}-\mathrm{C}$ catalysts contain two types of $\mathrm{FeN}_{4}$ active sites embedded in graphene structures, which show different catalytic activities and durabilities during the ORR. ${ }^{2,3,10,11,13}$ The porphyrinic $\mathrm{FeN}_{4}$ active site is surrounded by a 16 -membered ring (the socalled S1 site) and is highly active but shows poor durability during the ORR under acidic conditions. The more compact $\mathrm{FeN}_{4}$ active site is surrounded by a 14 -membered ring (the socalled S2 site) and less active than the S1 site but has a much higher durability. ${ }^{2,3}$ In addition, the previous studies on FePc and $\mathrm{Fe}$ porphyrins have suggested that $\mathrm{Fe}-\mathrm{N}$ distance can tune their stability. ${ }^{16}$ Therefore, one may consider that $\mathrm{FeN}_{4}$ structures with compact moieties, more specifically, short $\mathrm{Fe}-\mathrm{N}$ bonds, are desirable for new $\mathrm{Fe}-\mathrm{N}-\mathrm{C}$ catalysts. ${ }^{17,18}$ In fact, our research group has recently developed an Fe complex with a 14-membered hexaaza macrocyclic ligand (Fe(II) 1,14:7,8-ditethenotetrapyrido-[2,1,6-de:2', $1^{\prime} 6^{\prime}-g h: 2^{\prime \prime}, 1^{\prime \prime}, 6^{\prime \prime}$ $\left.k l: 2^{\prime \prime \prime}, 1^{\prime \prime \prime}, 6^{\prime \prime \prime}-n a\right][1,3,5,8,10,12]$ hexaazacyclotetradecine, re-

Received: July 12, 2021

Published: September 20, 2021 
ferred to as Fe-14MR), as shown in Figure $1 .{ }^{17}$ The number of $\mathrm{N}$ atoms in Fe-14MR is the same as that of FePc, but the (a)

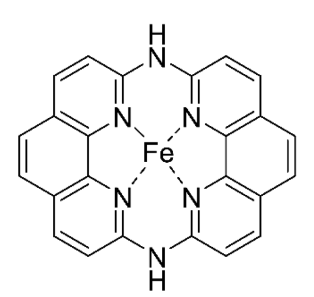

(b)

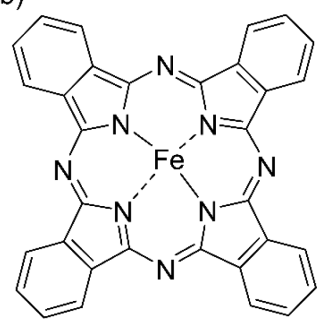

Figure 1. (a) The Fe-14MR complex used in this study, which has a 14-membered hexaaza macrocyclic ring. (b) FePc with a 16membered ring, which was used as a reference catalyst. The numbers of the rings, 14 and 16, indicate the numbers of atoms surrounding the Fe centers.

numbers of all atoms surrounding the $\mathrm{Fe}$ centers are smaller than FePc. In fact, a previous study demonstrated that $\mathrm{Fe}$ 14MR has a shorter $\mathrm{Fe}-\mathrm{N}$ bond length $(1.9 \AA)$ than $\mathrm{Fe}$ porphyrin $(2.0 \AA)){ }^{17}$ Furthermore, Fe-14MR exhibits better ORR activity than FePc under both acidic and basic electrolyte conditions. ${ }^{17}$ It is assumed that the superior catalytic activity of Fe-14MR is attributed to the strong coordination of the compact macrocyclic ligand. One may expect that the compact ligand also has the advantage of stability, as it strongly holds the $\mathrm{Fe}$ center; however, the stability of Fe-14MR has not yet been studied.

As such, we are interested in fully investigating the stability of Fe-14MR under electrochemical conditions. According to the literature, one of the main reasons for the degradation of $\mathrm{FeN}_{4}$ active sites in pyrolyzed $\mathrm{Fe}-\mathrm{N}-\mathrm{C}$ catalysts is demetalation during the ORR, which is caused by the protonation of basic $\mathrm{N}$ atoms and/or the degradation of carbon by reactive oxygen species. ${ }^{2,3,19-21}$ The kinetics of $\mathrm{Fe}$ demetalation at controlled potentials has been directly evaluated in a pyrolyzed $\mathrm{Fe}-\mathrm{N}-\mathrm{C}$ catalyst using in situ ${ }^{57} \mathrm{Fe}$ Mössbauer spectroscopy, which revealed demetalation of $80-$ $90 \%$ of the S1 site and almost no variation of the S2 site after $50 \mathrm{~h}$ of operation at $0.5 \mathrm{~V}$ in PEMFC single-cell tests. ${ }^{2,22}$ Realtime observations of demetalation in half-cell tests have been performed using in situ inductively coupled plasma mass spectrometry (ICP-MS); in this method, electrolyte solutions containing dissolved metals from pyrolyzed $\mathrm{Fe}-\mathrm{N}-\mathrm{C}$ catalysts can be monitored during electrochemical measurements. ${ }^{20,23-25}$ However, ICP-MS does not provide information on the electronic state or local structure of Fe active sites. Meanwhile, in situ X-ray absorption spectroscopy (XAS) has been used to investigate structural variations in $\mathrm{Fe}-\mathrm{N}-\mathrm{C}$ catalysts and their redox during the ORR in electrolyte solutions and PEMFC single-cell tests. ${ }^{19,20,25-28}$ Although the in situ XAS technique has not been applied in the quantitative analysis of demetalation, it has the potential to record demetalation in real time by monitoring $\mathrm{Fe}$ signals, which depend on $\mathrm{Fe}$ concentration.

In the present study, we quantitatively analyzed the degradation of Fe-14MR under electrochemical conditions in real time by in situ XAS. Carbon-supported Fe-14MR (Fe$14 \mathrm{MR} / \mathrm{C})$ and $\mathrm{FePc}(\mathrm{FePc} / \mathrm{C})$ were prepared, and their structures and demetalation behavior were evaluated to compare the durability of the Fe active site in a 14-membered ring to that in a 16-membered ring. The relationship between
$\mathrm{Fe}-\mathrm{N}$ bond length and catalyst durability is discussed to provide new insights into the development of durable macrocyclic complexes for the ORR under acidic conditions.

\section{RESULTS AND DISCUSSION}

Fe-14MR was synthesized according to a previous report. ${ }^{17} \mathrm{Fe}-$ $14 \mathrm{MR} / \mathrm{C}$ was prepared by impregnating an aqueous solution of $\mathrm{Fe}-14 \mathrm{MR}$ with carbon black (Ketjen EC600JD) at $85^{\circ} \mathrm{C}$. The amount of $\mathrm{Fe}$ in $\mathrm{Fe}-14 \mathrm{MR} / \mathrm{C}$ was determined to be $0.6 \mathrm{wt} \%$ by electron probe microanalysis (EPMA). Furthermore, the electrochemically active $\mathrm{Fe}$ density was evaluated to be 19 $\mu$ mol g${ }^{-1}$ using a $\mathrm{NO}_{2}{ }^{-}$reduction method. ${ }^{29}$ As a reference catalyst, $\mathrm{FePc} / \mathrm{C}$ was prepared by impregnating a $\mathrm{H}_{2} \mathrm{SO}_{4}$-based solution of $\mathrm{FePc}$ with carbon, as reported in the literature. ${ }^{27,28}$ The amount of $\mathrm{Fe}$ and the electrochemically active $\mathrm{Fe}$ density in $\mathrm{FePc} / \mathrm{C}$ were determined to be 0.7 wt $\%$ and $9 \mu \mathrm{mol} \mathrm{g}^{-1}$ by EPMA and a $\mathrm{NO}_{2}^{-}$reduction method, respectively. The Fe amounts and the electrochemically active $\mathrm{Fe}$ densities of the catalysts are summarized in Table 1.

Table 1. Fe Loadings and Electrochemically Active Fe Densities of Fe-14MR/C and FePc/C

$\begin{array}{ccc}\text { sample } & \text { Fe loading }{ }^{a} / \text { wt }^{2} & \text { active Fe density }^{b} / \mu \mathrm{mol} \mathrm{g}^{-1} \\ \mathrm{Fe}-14 \mathrm{MR} / \mathrm{C} & 0.6 & 19 \\ \mathrm{FePc} / \mathrm{C} & 0.7 & 9\end{array}$

${ }^{a}$ Determined by EPMA. ${ }^{b}$ Determined by a $\mathrm{NO}_{2}{ }^{-}$reduction method.

The structure of Fe-14MR/C was analyzed by ex situ XAS. Figure 2(a) shows the Fe K-edge X-ray absorption near edge
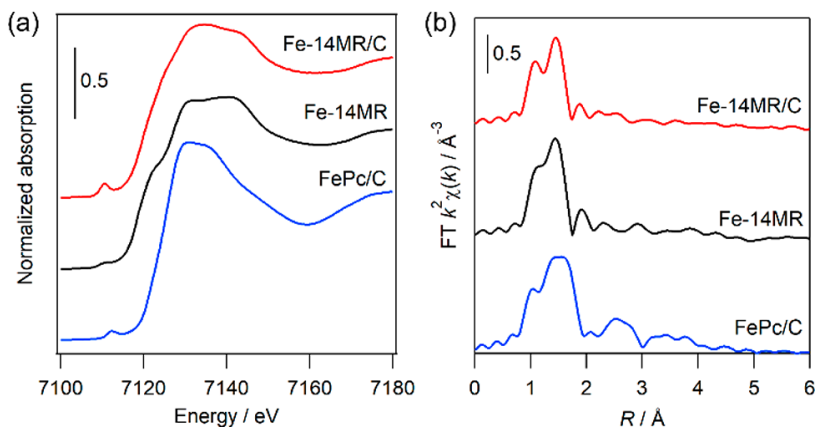

Figure 2. Fe K-edge (a) XANES and (b) FT EXAFS spectra of Fe$14 \mathrm{MR} / \mathrm{C}, \mathrm{Fe}-14 \mathrm{MR}$, and $\mathrm{FePc} / \mathrm{C}$.

structure (XANES) spectra of Fe-14MR/C, Fe-14MR, and $\mathrm{FePc} / \mathrm{C}$. Fe-14MR/C exhibits spectral features that are slightly different than those of Fe-14MR. Specifically, the pre-edge peak for $\mathrm{Fe}-14 \mathrm{MR} / \mathrm{C}$ is of higher intensity than the pre-edge peak for Fe-14MR. A pre-edge peak is also observed in the $\mathrm{FePc} / \mathrm{C}$ spectrum. An increase in the pre-edge peak intensity indicates that the symmetry around the $\mathrm{Fe}$ species is distorted by Fe-14MR being loaded on carbon. ${ }^{30}$ Thus, one can consider that the axial ligands of $\mathrm{Fe}-14 \mathrm{MR}$ are changed by the adsorption of Fe-14MR on carbon. Figure 2(b) shows the Fourier transforms (FTs) of the Fe K-edge extended X-ray absorption fine structure (EXAFS) spectra of Fe-14MR/C, Fe$14 \mathrm{MR}$, and $\mathrm{FePc} / \mathrm{C}$; peaks are observed at 1-2 $\AA$ (Figure S1: EXAFS oscillations). Table 2 presents the curve-fitting analysis results for the peaks observed at 1-2 A. The Fe-14MR/C peak is fitted by a model comprising four $\mathrm{Fe}-\mathrm{N}$ bonds with lengths of $1.90 \AA$ and two $\mathrm{Fe}-\mathrm{O}$ bonds with lengths of $2.12 \AA$. The $R$ - 
Table 2. EXAFS Curve-Fitting Results for Fe-14MR/C, Fe14MR, and $\mathrm{FePc} / \mathrm{C}^{a}$

$\begin{array}{lcccccc}\text { sample } & \text { atom } & N^{b} & R^{c} / \AA & \sigma^{2 d} / \AA^{2} & E_{0}{ }^{e} & \begin{array}{c}R- \\ \text { factor }\end{array} \\ \mathrm{Fe}-14 \mathrm{MR} / \mathrm{C} & \mathrm{N} & 4 & 1.90(4) & 0.005(2) & 7117(7) & 0.035 \\ & \mathrm{O} & 2 & 2.12(7) & 0.017(19) & & \\ \mathrm{Fe}-14 \mathrm{MR} & \mathrm{N} & 4 & 1.88(2) & 0.003(1) & 7116(4) & 0.016 \\ & \mathrm{O} & 2 & 2.14(4) & 0.014(9) & & \\ \mathrm{FePc} / \mathrm{C} & \mathrm{N} & 4 & 2.03(2) & 0.004(1) & 7117(2) & 0.007 \\ & \mathrm{O} & 1 & 1.85(2) & 0.001(2) & & \end{array}$

${ }^{a}$ FT range: $3-14 \AA^{-1}$, curve-fitting range: $1.0-2.0 \AA .{ }^{b}$ Coordination number. ${ }^{c}$ Atomic distance. ${ }^{d}$ Debye-Waller factor. ${ }^{e}$ Absorption edge energy.

factor suggests that the model is the most accurate. The Fe-N and $\mathrm{Fe}-\mathrm{O}$ bond lengths are nearly identical to those of Fe$14 \mathrm{MR}$ and those determined previously by single-crystal analysis. ${ }^{17}$ For FePc/C, the peak at $1-2 \AA$ is well-fitted by a model comprising four $\mathrm{Fe}-\mathrm{N}$ bonds with lengths of $2.03 \AA$ and one $\mathrm{Fe}-\mathrm{O}$ bond with a length of $1.85 \AA$. Therefore, Fe-14MR/ $\mathrm{C}$ has shorter $\mathrm{Fe}-\mathrm{N}$ bonds than $\mathrm{FePc} / \mathrm{C}$. In other words, the Fe active sites within $\mathrm{Fe}-14 \mathrm{MR} / \mathrm{C}$ have a smaller coordinated structure than those within $\mathrm{FePc} / \mathrm{C}$.

Linear sweep voltammetry (LSV) was performed on $\mathrm{Fe}$ $14 \mathrm{MR} / \mathrm{C}$ using a rotating disk electrode (RDE) at $2500 \mathrm{rpm}$ in an $\mathrm{O}_{2}$-saturated, $0.5 \mathrm{M} \mathrm{H}_{2} \mathrm{SO}_{4}$ aqueous solution. To evaluate the durability of $\mathrm{Fe}-14 \mathrm{MR} / \mathrm{C}$, ORR curves were obtained before and after 50 potential sweep cycles between 1.0 and $0 \mathrm{~V}$ at $50 \mathrm{mV} \mathrm{sec}^{-1}$ in $\mathrm{O}_{2}$-saturated $0.5 \mathrm{M} \mathrm{H}_{2} \mathrm{SO}_{4}$. For comparison, the ORR performance of $\mathrm{FePc} / \mathrm{C}$ was also determined under the same conditions as those for Fe-14MR/C. To compare the catalytic activity of $\mathrm{Fe}-14 \mathrm{MR} / \mathrm{C}$ and $\mathrm{FePc} / \mathrm{C}$, their turnover frequencies (TOFs) were evaluated from the current at $0.75 \mathrm{~V}$ vs RHE (before 50 potential sweep cycles) and the Fe active site densities. As presented in Table 3, the TOF of Fe-14MR/

Table 3. TOFs of Fe-14MR/C and FePc/C for the ORR at $0.75 \mathrm{~V}$ vs $\mathrm{RHE}^{a}$

\begin{tabular}{lc}
\multicolumn{1}{c}{ sample } & TOF/e site $\mathrm{s}^{-1} \mathrm{~s}^{-1}$ \\
$\mathrm{Fe}-14 \mathrm{MR} / \mathrm{C}$ & 0.39 \\
$\mathrm{FePc} / \mathrm{C}$ & 0.08
\end{tabular}

${ }^{a_{\mathrm{TOF}}}=i / d / F$, where $i$ is the current per unit catalyst weight $\left(\mathrm{A} \mathrm{g}^{-1}\right)$ at $0.75 \mathrm{~V}$ vs RHE, $d$ is the electrochemically active Fe density (mol $\left.\mathrm{g}^{-1}\right)$, and $F$ is the Faraday constant $\left(\mathrm{C} \mathrm{mol}^{-1}\right)$.

$\mathrm{C}$ showed a significantly higher value than that of $\mathrm{FePc} / \mathrm{C}$. Therefore, the electrochemically active $\mathrm{Fe}$ site of $\mathrm{Fe}-14 \mathrm{MR} / \mathrm{C}$ has higher catalytic activity for the ORR than that of $\mathrm{FePc} / \mathrm{C}$.

For both catalysts, the ORR onset potential shifted to a lower potential after cycling (Figure 3), suggesting that the catalysts degraded during the ORR. However, the shift in the onset potential for $\mathrm{Fe}-14 \mathrm{MR} / \mathrm{C}$ was much smaller than that for $\mathrm{FePc} / \mathrm{C}$, indicating that $\mathrm{Fe}-14 \mathrm{MR} / \mathrm{C}$ is more stable than $\mathrm{FePc} /$ $\mathrm{C}$ during the ORR under acidic conditions. It is reasonable to consider that the high stability of $\mathrm{Fe}-14 \mathrm{MR} / \mathrm{C}$ is derived from the active $\mathrm{Fe}$ species being highly resistant to demetalation in acidic media during the ORR. 2,22,23,25 Meanwhile, previous works have suggested the low stability of Fe-14MR (without carbon support) for acidic ORR, which is different from the results of this study. ${ }^{17,18}$ The difference would be derived from the supported form of $\mathrm{Fe}-14 \mathrm{MR} / \mathrm{C}$, since in the previous

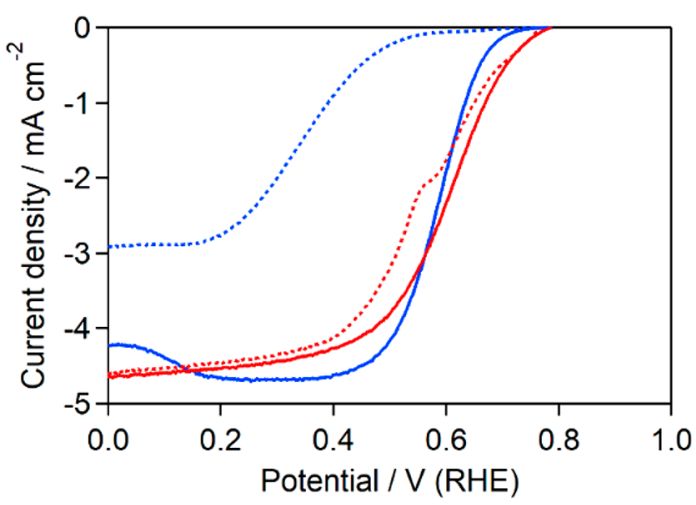

Figure 3. ORR LSV curves for Fe-14MR/C (red curve) and FePc/C (blue curve) before (solid curves) and after (dotted curves) 50 potential sweep cycles between 1.0 and $0 \mathrm{~V}$. The $\mathrm{RDE}$ was rotated at $1600 \mathrm{rpm}$ in $\mathrm{O}_{2}$-saturated $0.5 \mathrm{M} \mathrm{H}_{2} \mathrm{SO}_{4}$.

studies, the stability of Fe-14MR was evaluated using a simply mixed catalyst of Fe-14MR and carbon black.

To determine the dissolution behavior of the Fe species in $\mathrm{Fe}-14 \mathrm{MR} / \mathrm{C}$, in situ XAS measurements were performed according to the procedure outlined in Table 4. First, the redox

Table 4. In Situ XAS Procedure during Electrochemical Measurements

\begin{tabular}{cl} 
step no. & \multicolumn{1}{c}{ measurement } \\
1 & CV under $\mathrm{N}_{2}$ \\
2 & XANES at $0.9 \mathrm{~V}$ under $\mathrm{N}_{2}$ \\
3 & XANES at $0.3 \mathrm{~V}$ under $\mathrm{N}_{2}$ \\
4 & X-ray fluorescence monitoring during $\mathrm{CV} ; 30$ cycles under $\mathrm{N}_{2}$ \\
5 & X-ray fluorescence monitoring during $\mathrm{CV} ; 125$ cycles under $\mathrm{O}_{2}$ \\
6 & XANES at $0.9 \mathrm{~V}$ under $\mathrm{N}_{2}$ \\
7 & XANES at $0.3 \mathrm{~V}$ under $\mathrm{N}_{2}$ \\
8 & CV under $\mathrm{N}_{2}$
\end{tabular}

behavior of the Fe species was evaluated under $\mathrm{N}_{2}$ by cyclic voltammetry (CV, step 1$)$, and XANES spectra were obtained with the cathode potential held at either 0.9 or $0.3 \mathrm{~V}$ vs RHE (steps 2 and 3, respectively). Then, the electrode Fe content during $\mathrm{CV}$ under $\mathrm{N}_{2}$ and $\mathrm{O}_{2}$ was determined from the X-ray fluorescence of the $\mathrm{Fe}$ species during synchrotron X-ray radiation $(8214 \mathrm{eV})$ (steps 4 and 5, respectively). It should be noted that the reason for monitoring the $\mathrm{X}$-ray fluorescence of Fe species under both $\mathrm{N}_{2}$ and $\mathrm{O}_{2}$ is to confirm that the ORR triggered demetalation. ${ }^{14,15}$ Changes in the redox behavior and structure of the catalyst after 155 potential cycles were evaluated by additional XAS measurements (steps 6 and 7) and $\mathrm{CV}$ under $\mathrm{N}_{2}$ (step 8). FePc/C was studied in the same manner for comparison.

The $\mathrm{CV}$ results for $\mathrm{Fe}-14 \mathrm{MR} / \mathrm{C}$ under $\mathrm{N}_{2}$ (step 1) are shown in Figure 4(a), and anodic and cathodic peaks are observed at 0.75 and $0.72 \mathrm{~V}$, respectively. Figure 5(a) presents the XANES spectra of Fe-14MR/C obtained during steps 2 and 3 at 0.9 and $0.3 \mathrm{~V}$, respectively; these potentials were higher and lower than the CV peaks, respectively. The features of the $\mathrm{Fe}-14 \mathrm{MR} / \mathrm{C}$ spectrum changed with the applied potential. Specifically, the X-ray absorption edge shifted to a lower energy as the potential changed from 0.9 to $0.3 \mathrm{~V}$. This edge shift indicates that $\mathrm{Fe}-14 \mathrm{MR} / \mathrm{C}$ was reduced. Considering the previously reported relationship between edge energy and formal $\mathrm{Fe}$ valence, ${ }^{17} \mathrm{Fe}$ in $\mathrm{Fe}-14 \mathrm{MR} / \mathrm{C}$ was presumably 


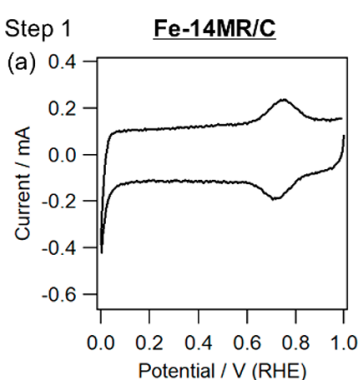

Step 4

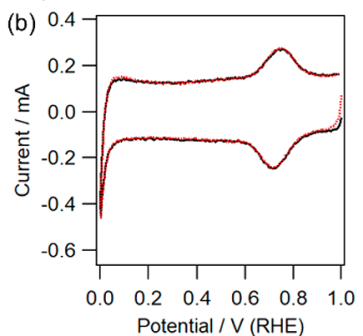

Step 5

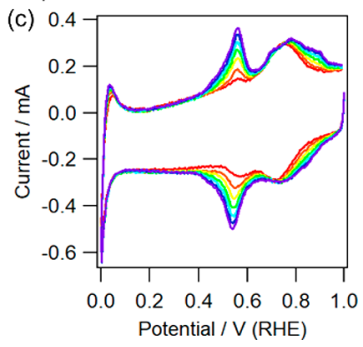

reduced from $\mathrm{Fe}^{3+}$ to $\mathrm{Fe}^{2+}$ when the potential was swept from 0.9 to $0.3 \mathrm{~V}$. Thus, the CV peaks in Figure 4(a) are considered to involve $\mathrm{Fe}^{3+/ 2+}$ redox. The XANES spectra of $\mathrm{Fe}-14 \mathrm{MR} / \mathrm{C}$ after the $\mathrm{CV}$ cycles performed in steps 6 and 7 are also shown in Figure 5(a). The spectrum at each potential was similar to that obtained before the CV cycles performed in steps 2 and 3 , confirming that the chemical structure surrounding the $\mathrm{Fe}$ centers was retained even after 155 potential cycles and $\mathrm{Fe}^{3+/ 2+}$ redox.

Figure $4(b, c)$ show the CV curves obtained at steps 4 and 5 . The features of the $\mathrm{CV}$ curve did not change during $\mathrm{CV}$ cycling under $\mathrm{N}_{2}$ (step 4 ). In contrast, the $\mathrm{CV}$ features clearly changed during $\mathrm{CV}$ cycling under $\mathrm{O}_{2}$ (step 5). The $\mathrm{CV}$ cycling caused an increase of peaks at 0.55 and $0.8-0.9 \mathrm{~V}$, while the current at $0.75 \mathrm{~V}$ did not significantly change. Although the reason for the variation of the $\mathrm{CV}$ feature has not yet been revealed, it seems that demetalation of $\mathrm{Fe}$ is not the main cause of the variation of the $\mathrm{CV}$ feature, because the current at 0.75 $\mathrm{V}$ was almost constant during the $\mathrm{CV}$ cycles. It should also be noted that the XANES spectra obtained after the CV performed in steps 6 and 7 were slightly different from those obtained after steps 2 and 3 , suggesting that the coordination environment around the Fe species slightly changed. Thus, the difference in the $\mathrm{CV}$ curves as well as that in the ORR curves (Figure 3) may be due to changes in the ligands such as variation of the amine groups to imine groups within Fe-14MR during the ORR. More importantly, the intensity of the $\mathrm{CV}$ peaks was not diminished after 125 cycles under $\mathrm{O}_{2}$, suggesting that Fe-14MR/C is resistant to Fe dissolution during the ORR.

For comparison, the $\mathrm{CV}$ curves for $\mathrm{FePc} / \mathrm{C}$ obtained at steps 1,4 , and 5 are presented in Figure $4(\mathrm{~d}-\mathrm{f})$. In addition, the XANES spectra of $\mathrm{FePc} / \mathrm{C}$ before and after $\mathrm{CV}$ cycling are shown in Figure 5(b). The XANES spectra change due to the redox of $\mathrm{FePc} / \mathrm{C}$; the absorption edge energy shifts due to $\mathrm{Fe}^{3+}$ transforming into $\mathrm{Fe}^{2+}$. This result is consistent with those of a previous report on $\mathrm{FePc} / \mathrm{C}^{27,28}$ The change in the $\mathrm{FePc} / \mathrm{C}$ spectra is similar to that observed in the $\mathrm{Fe}-14 \mathrm{MR} / \mathrm{C}$ spectra. However, trends in the $\mathrm{CV}$ curves for $\mathrm{FePc} / \mathrm{C}$ are different from those in the $\mathrm{CV}$ curves for $\mathrm{Fe}-14 \mathrm{MR} / \mathrm{C}$. The intensity of the $\mathrm{CV}$ peaks for the $\mathrm{FePc} / \mathrm{C}$ decrease with increasing $\mathrm{CV}$ cycle number, especially under $\mathrm{O}_{2}$ (Figure 4(f)). This suggests that $\mathrm{FePc} / \mathrm{C}$ is vulnerable to the dissolution of $\mathrm{Fe}$ species during the ORR.

To evaluate the demetalation of the catalysts during the ORR, changes in the amount of $\mathrm{Fe}$ in the catalysts during $\mathrm{CV}$ cycling under $\mathrm{N}_{2}$ and $\mathrm{O}_{2}$ (steps 4 and 5) were investigated; Federived X-ray fluorescence was monitored under X-ray irradiation at $8214 \mathrm{eV}$. The Fe-derived X-ray fluorescence of the catalysts was determined by subtracting the X-ray fluorescence of a blank in situ XAS cell without the catalysts from the X-ray fluorescence of XAS cells with the catalysts. Then, relative changes in the Fe concentration of the catalysts were evaluated. Figure 6 shows the relative decrease in $\mathrm{Fe}$ concentration observed for $\mathrm{Fe}-14 \mathrm{MR} / \mathrm{C}$ and $\mathrm{FePc} / \mathrm{C}$ during the $\mathrm{CV}$ cycles performed in steps 4 and 5 . The relative concentration of $\mathrm{Fe}$ in $\mathrm{Fe}-14 \mathrm{MR} / \mathrm{C}$ was nearly unchanged under $\mathrm{N}_{2}$ but decreased under $\mathrm{O}_{2}$ with repeated cycling. This result indicates that leaching of $\mathrm{Fe}$ species into the electrolyte solution is faster under $\mathrm{O}_{2}$. Thus, the demetalation of $\mathrm{Fe}$ species is considered to be caused by activated oxygen species formed during the ORR. ${ }^{2,14,15,20,31}$ More importantly, the relative concentration of $\mathrm{Fe}$ decreased less and more slowly in $\mathrm{Fe}-14 \mathrm{MR} / \mathrm{C}$ than in $\mathrm{FePc} / \mathrm{C}$. The smaller decrease was 


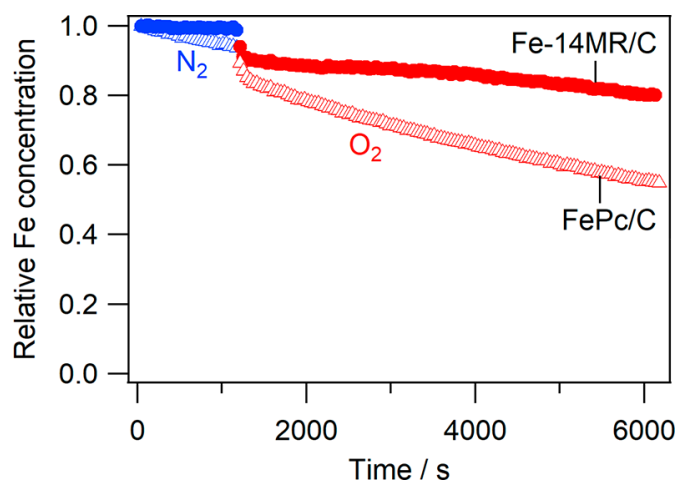

Figure 6. Changes in the relative concentration of $\mathrm{Fe}$ in $\mathrm{Fe}-14 \mathrm{MR} / \mathrm{C}$ $(\mathbf{0})$ and $\mathrm{FePc} / \mathrm{C}(\Delta)$ during $\mathrm{CV}$ cycling under $\mathrm{N}_{2}$ (step 4) (blue) and $\mathrm{O}_{2}$ (step 5) (red).

confirmed by the raw XANES spectra before absorption normalization (Figure S2). Therefore, Fe-14MR/C is more stable than $\mathrm{FePc} / \mathrm{C}$ with respect to the leaching of $\mathrm{Fe}$ species during the ORR. The high stability of $\mathrm{Fe}-14 \mathrm{MR} / \mathrm{C}$ accounts for its highly durable ORR performance (Figure 3). It should also be noted that the decreased ratio of Fe content in Figure 6 is not consistent with that of ORR activity in Figure 3. More specifically, the ORR activity of $\mathrm{FePc} / \mathrm{C}$ was almost completely diminished after only the $50 \mathrm{CV}$ cycles, but about $50 \%$ of $\mathrm{Fe}$ content was remained on $\mathrm{FePc} / \mathrm{C}$ even after the $125 \mathrm{CV}$ cycles. In other words, the Fe content should be much smaller if all Fe species detected in the in situ XAS experiment had been active for the ORR. The results suggest that some of $\mathrm{Fe}$ species exist as inactive species on an electrode after the $\mathrm{CV}$ cycles. There are two possible structures of ORR-inactive Fe species: Fe oxide nanoparticles and bulk Fe species in a stack or crystalline of $\mathrm{Fe}$ complexes. If the $\mathrm{Fe}$ oxide nanoparticles had been formed as the main deactivated species, the XANES spectral feature would have largely changed after the CV cycles. But the actual change in XANES spectra of the $\mathrm{Fe}$ complexes is slight, suggesting that the Fe species in the inside of a stack or crystal are the main inactive Fe species remaining after the $\mathrm{CV}$ cycles. As described above, the amount of exposed $\mathrm{Fe}$ active species in $\mathrm{Fe}-14 \mathrm{MR} / \mathrm{C}$ is about twice as large as that in $\mathrm{FePc} / \mathrm{C}$ at almost the same $\mathrm{Fe}$ content (Table 1). This means that the difference in the stability between Fe-14MR/C and $\mathrm{FePc} / \mathrm{C}$ is more than that observed in Figure 6. In other words, the stability of $\mathrm{Fe}-14 \mathrm{MR} / \mathrm{C}$ is significantly superior to that of $\mathrm{FePc} / \mathrm{C}$. It is reasonable to consider that the shorter $\mathrm{Fe}-\mathrm{N}$ bond length in $\mathrm{Fe}-14 \mathrm{MR}$, with respect to the $\mathrm{Fe}-\mathrm{N}$ bond lengths in conventional Fe complexes with 16-membered rings, is key to the stability of the $\mathrm{Fe}$ species in Fe-14MR during the ORR.

\section{CONCLUSIONS}

The structural effect of the $\mathrm{FeN}_{4}$ moiety on durability under acidic ORR conditions was investigated by comparing $\mathrm{Fe}$ $14 \mathrm{MR} / \mathrm{C}$ and $\mathrm{FePc} / \mathrm{C}$. Structural analysis using EPMA and XAS confirmed that $\mathrm{Fe}-14 \mathrm{MR} / \mathrm{C}$ and $\mathrm{FePc} / \mathrm{C}$ contain a similar amount of $\mathrm{Fe}$ species, but $\mathrm{Fe}-14 \mathrm{MR} / \mathrm{C}$ has a shorter $\mathrm{Fe}-\mathrm{N}$ bond length. An electrochemical ORR study indicated that Fe$14 \mathrm{MR} / \mathrm{C}$ is more durable than $\mathrm{FePc} / \mathrm{C}$. In situ XAS analysis demonstrated that the demetalation of $\mathrm{Fe}-14 \mathrm{MR} / \mathrm{C}$ is accelerated under $\mathrm{O}_{2}$, and more importantly, $\mathrm{Fe}-14 \mathrm{MR} / \mathrm{C}$ is more resistant to demetalation during the ORR than $\mathrm{FePc} / \mathrm{C}$. Therefore, it is revealed that 14-membered ring ligands can improve the durability of Fe catalysts during the ORR by improving the resistance of these catalysts to Fe leaching in acidic media. The results of this study are consistent with the structure-property relationships observed in $\mathrm{Fe}-\mathrm{N}-\mathrm{C}$ catalysts. More importantly, the results suggest that compact $\mathrm{Fe}$ complexes with 14-membered ring ligands can be used for the ORR under acidic conditions without pyrolysis, whereas conventional $\mathrm{Fe}$ complexes with 16-membered rings cannot be used because of their poor stability. Therefore, a new and more rational NPM catalyst design may be developed by preparing 14-membered $\mathrm{Fe}$ complexes with three-dimensional architectures or loading them onto catalytic supports with high surface areas. Further studies will be performed to modify the ligand structure and tune the catalytic activity and stability of these promising Fe complexes.

\section{METHODS}

\section{Catalyst Preparation}

Fe-14MR was synthesized according to a previous study. ${ }^{17} \mathrm{Fe}-14 \mathrm{MR} /$ $\mathrm{C}$ was prepared by impregnating an aqueous solution $(200 \mathrm{~mL})$ of $\mathrm{Fe}-$ $14 \mathrm{MR}(101 \mathrm{mg})$ (yellow-blue in color) with Ketjen black $(500 \mathrm{mg})$ at $85{ }^{\circ} \mathrm{C}$. After stirring for $2 \mathrm{~h}$, the suspension was filtered; then, the solid was washed with water $(100 \mathrm{~mL})$ and dried overnight at $120^{\circ} \mathrm{C}$ to obtain $\mathrm{Fe}-14 \mathrm{MR} / \mathrm{C}$. $\mathrm{FePc} / \mathrm{C}$ was prepared according to the literature. ${ }^{27,28} \mathrm{FePc}(20 \mathrm{mg})$ was dissolved in $\mathrm{H}_{2} \mathrm{SO}_{4}$; Ketjen black $(49 \mathrm{mg})$ was then added. The suspension was stirred for $1 \mathrm{~h}$ at room temperature, diluted with water $(200 \mathrm{~mL})$ in an ice bath, and then filtered. The suspension was washed with water until the $\mathrm{pH}$ of the filtrate was $6-7$; the residue was dried overnight at $110^{\circ} \mathrm{C}$ to obtain $\mathrm{FePc} / \mathrm{C}$.

\section{Catalyst Characterization}

The amount of $\mathrm{Fe}$ in $\mathrm{Fe}-14 \mathrm{MR} / \mathrm{C}$ and $\mathrm{FePc} / \mathrm{C}$ was determined using an electron probe microanalyser (JXA-8100, JEOL) with a wavelength dispersive spectrometer; an LIFH crystal was used to detect Fe. EPMA samples were prepared by pelletizing catalyst powders; no binder was used. Electrochemically active $\mathrm{Fe}$ density was evaluated using a $\mathrm{NO}_{2}{ }^{-}$reduction method. ${ }^{29}$ In this method, $\mathrm{NO}_{2}{ }^{-}$was coordinated to $\mathrm{Fe}$ active sites by immersing $\mathrm{Fe} 14 \mathrm{MR} / \mathrm{C}$ in a $\mathrm{NaNO}_{2}$ aqueous solution and then reduced by sweeping potential from 0.4 to $-0.3 \mathrm{~V}$ vs RHE, where cathodic current was obtained by reductive stripping of $\mathrm{NO}$ on the Fe active sites. From the cathodic current, the amount of electrochemically active Fe species was determined.

XAFS measurements were performed at the BL5S1 beamline at the Aichi Synchrotron Radiation Center in Japan. The spectra were obtained in transmission mode. The spectral analysis was performed using Athena and Artemis software included in the Demeter package.

\section{ORR Activity Tests}

ORR durability tests were performed using a Nikko Keisoku RDE-1 system with an HZ-7000 bipotentiostat (Hokuto Denko). A catalyst ink was prepared by dispersing the catalyst powder $(5 \mathrm{mg})$ in a solution containing water $(150 \mu \mathrm{L})$, ethanol $(150 \mu \mathrm{L})$, and Nafion DE521 (Sigma-Aldrich, $50 \mu \mathrm{L})$. The prepared ink $(4 \mu \mathrm{L})$ was coated on the glassy carbon disk $\left(0.283 \mathrm{~cm}^{2}\right)$ of a rotating ring-disk electrode (RRDE) to a final loading of $200 \mu \mathrm{g}_{\text {cat }} \mathrm{cm}^{-2}$ (Figure S3). Linear sweep voltammograms $\left(10 \mathrm{mV} \mathrm{sec}{ }^{-1}\right)$ were obtained at a rotation speed of $1600 \mathrm{rpm}$ in a $\mathrm{N}_{2}$-saturated, $0.5 \mathrm{M} \mathrm{H}_{2} \mathrm{SO}_{4}$ aqueous solution and an $\mathrm{O}_{2}$-saturated solution. The current resulting from the ORR was determined by subtracting the current obtained under $\mathrm{N}_{2}$ from that obtained under $\mathrm{O}_{2}$. After the LSV measurements, 50 potential sweep cycles were carried out between 1.0 and $0 \mathrm{~V}$ at $50 \mathrm{mV} \mathrm{sec}^{-1}$ in the same $\mathrm{O}_{2}$-saturated, $0.5 \mathrm{M} \mathrm{H}_{2} \mathrm{SO}_{4}$ aqueous solution; these cycles were performed to accelerate degradation. After cycling, LSV was performed under $\mathrm{O}_{2}$ and $\mathrm{N}_{2}$. 


\section{In Situ XAS Measurements}

A schematic diagram of the in situ XAS setup is presented in Figure S4. ${ }^{32}$ The catalyst ink was dispersed on a polished, glassy carbon plate; the ink formed a circle with a diameter of $0.5 \mathrm{~cm}$, and the catalyst loading was $0.4 \mathrm{mg}_{\mathrm{cat}} \mathrm{cm}^{-2}$. The catalyst-coated plate acted as the working electrode. An RHE and a Pt counter electrode were placed in a glass cell filled with a $0.5 \mathrm{M} \mathrm{H}_{2} \mathrm{SO}_{4}$ aqueous solution. The electrolyte was saturated with $\mathrm{N}_{2}$ or $\mathrm{O}_{2}$ by bubbling the solution with each gas at a flow rate of $20 \mathrm{~mL} \mathrm{~min}{ }^{-1}$ for $10 \mathrm{~min}$. The electrodes were connected to an HZ-7000 potentiostat (Hokuto Denko Corp.). $\mathrm{Fe} \mathrm{K}$-edge X-ray absorption and X-ray fluorescence were measured by irradiating the catalyst on the carbon plate with synchrotron X-rays; the potential of the working electrode was controlled. X-ray fluorescence was monitored with a multielement, solid-state silicon drift detector (SSD). The Fe content was evaluated from the X-ray fluorescence at $8214 \mathrm{eV}$ acquired for $40 \mathrm{~s}$, which corresponds to the time for 1 cycle of CV. The in situ XAS experimental protocol is presented in Table 4. In situ XAS measurements were performed at the BL5S1 beamline at AichiSR. The spectra were analyzed using Athena software included in the Demeter package.

\section{ASSOCIATED CONTENT}

\section{Supporting Information}

The Supporting Information is available free of charge at https://pubs.acs.org/doi/10.1021/jacsau.1c00309.

EXAFS spectra, in situ XANES spectra, a schematic diagram of an in situ XAS cell, and a plot of the ORR current density against catalyst amount (PDF)

\section{AUTHOR INFORMATION}

\section{Corresponding Author}

Yuta Nabae - Department of Materials Science and Engineering, Tokyo Institute of Technology, Tokyo 152-8552, Japan; (1) orcid.org/0000-0002-9845-382X; Email:nabae.y.aa@m.titech.ac.jp

\section{Authors}

Junya Ohyama - Faculty of Advanced Science and Technology, Kumamoto University, Kumamoto 860-8555, Japan; orcid.org/0000-0002-7438-5236

Makoto Moriya - College of Science, Academic Institute, Shizuoka University, Shizuoka 422-8529, Japan; Department of Science, Graduate School of Integrated Science and Technology, Shizuoka University, Shizuoka 422-8529, Japan; (i) orcid.org/0000-0001-9582-1263

Ryo Takahama - Department of Science, Graduate School of Integrated Science and Technology, Shizuoka University, Shizuoka 422-8529, Japan

Kazuki Kamoi - Department of Science, Graduate School of Integrated Science and Technology, Shizuoka University, Shizuoka 422-8529, Japan

Shin Kawashima - Corporate Research \& Development, Asahi Kasei Corporation, Kurashiki, Okayama 711-8510, Japan

Ryoichi Kojima - Corporate Research \& Development, Asahi Kasei Corporation, Kurashiki, Okayama 711-8510, Japan

Teruaki Hayakawa - Department of Materials Science and Engineering, Tokyo Institute of Technology, Tokyo 152-8552, Japan; (i) orcid.org/0000-0002-1704-5841

Complete contact information is available at: https://pubs.acs.org/10.1021/jacsau.1c00309

\section{Author Contributions}

The manuscript was written through contributions of all authors. All authors have given approval to the final version of the manuscript.

Notes

The authors declare no competing financial interest.

\section{ACKNOWLEDGMENTS}

This study was financially supported by the New Energy and Industrial Technology Development Organization (NEDO). XAS measurements were obtained at the BL5S1 and BL11S2 beamlines at the Aichi Synchrotron Radiation Center in Japan (Proposal Nos. 201904003, 201905074, 202002021, and 202004072).

\section{REFERENCES}

(1) Chen, Z.; Higgins, D.; Yu, A.; Zhang, L.; Zhang, J. A review on non-precious metal electrocatalysts for PEM fuel cells. Energy Environ. Sci. 2011, 4, 3167-3192.

(2) Li, J.; Sougrati, M. T.; Zitolo, A.; Ablett, J. M.; Oguzz, I. C.; Mineva, T.; Matanovic, I.; Atanassov, P.; Huang, Y.; Zenyuk, I.; Di Cicco, A.; Kumar, K.; Dubau, L.; Maillard, F.; Dražić, G.; Jaouen, F. Identification of durable and non-durable $\mathrm{FeNx}$ sites in Fe-N-C materials for proton exchange membrane fuel cells. Nat. Catal. 2021, $4,10-19$.

(3) Liu, S.; Shi, Q.; Wu, G. Solving the activity-stability trade-off riddle. Nat. Catal. 2021, 4, 6-7.

(4) Banham, D.; Kishimoto, T.; Zhou, Y.; Sato, T.; Bai, K.; Ozaki, J.i.; Imashiro, Y.; Ye, S. Critical advancements in achieving high power and stable nonprecious metal catalyst-based MEAs for real-world proton exchange membrane fuel cell applications. Sci. Adv. 2018, 4, No. eaar7180.

(5) Nabae, Y.; Nagata, S.; Hayakawa, T.; Niwa, H.; Harada, Y.; Oshima, M.; Isoda, A.; Matsunaga, A.; Tanaka, K.; Aoki, T. Pt-free carbon-based fuel cell catalyst prepared from spherical polyimide for enhanced oxygen diffusion. Sci. Rep. 2016, 6, 23276.

(6) Nabae, Y.; Nagata, S.; Kusaba, K.; Aoki, T.; Hayakawa, T.; Tanida, H.; Imai, H.; Hori, K.; Yamamoto, Y.; Arai, S.; Ohyama, J. Magnetic purification of non-precious metal fuel cell catalysts for obtaining atomically dispersed $\mathrm{Fe}$ centers. Catal. Sci. Technol. 2020, 10, 493-501.

(7) Proietti, E.; Jaouen, F.; Lefêvre, M.; Larouche, N.; Tian, J.; Herranz, J.; Dodelet, J.-P. Iron-based cathode catalyst with enhanced power density in polymer electrolyte membrane fuel cells. Nat. Commun. 2011, 2, 416.

(8) Strickland, K.; Miner, E.; Jia, Q.; Tylus, U.; Ramaswamy, N.; Liang, W.; Sougrati, M.-T.; Jaouen, F.; Mukerjee, S. Highly active oxygen reduction non-platinum group metal electrocatalyst without direct metal-nitrogen coordination. Nat. Commun. 2015, 6, 7343.

(9) Wan, X.; Liu, X.; Li, Y.; Yu, R.; Zheng, L.; Yan, W.; Wang, H.; $\mathrm{Xu}, \mathrm{M}$.; Shui, J. Fe-N-C electrocatalyst with dense active sites and efficient mass transport for high-performance proton exchange membrane fuel cells. Nat. Catal. 2019, 2, 259-268.

(10) Mineva, T.; Matanovic, I.; Atanassov, P.; Sougrati, M.-T.; Stievano, L.; Clémancey, M.; Kochem, A.; Latour, J.-M.; Jaouen, F. Understanding Active Sites in Pyrolyzed Fe-N-C Catalysts for Fuel Cell Cathodes by Bridging Density Functional Theory Calculations and 57Fe Mössbauer Spectroscopy. ACS Catal. 2019, 9, 9359-9371.

(11) Wagner, S.; Auerbach, H.; Tait, C. E.; Martinaiou, I.; Kumar, S. C. N.; Kübel, C.; Sergeev, I.; Wille, H.-C.; Behrends, J.; Wolny, J. A.; Schünemann, V.; Kramm, U. I. Elucidating the Structural Composition of an Fe-N-C Catalyst by Nuclear- and ElectronResonance Techniques. Angew. Chem., Int. Ed. 2019, 58, 1048610492.

(12) Chung, H. T.; Cullen, D. A.; Higgins, D.; Sneed, B. T.; Holby, E. F.; More, K. L.; Zelenay, P. Direct atomic-level insight into the 
active sites of a high-performance PGM-free ORR catalyst. Science 2017, 357, 479-484.

(13) Zitolo, A.; Goellner, V.; Armel, V.; Sougrati, M.-T.; Mineva, T.; Stievano, L.; Fonda, E.; Jaouen, F. Identification of catalytic sites for oxygen reduction in iron- and nitrogen-doped graphene materials. Nat. Mater. 2015, 14, 937-942.

(14) Chen, Z.; Jiang, S.; Kang, G.; Nguyen, D.; Schatz, G. C.; Van Duyne, R. P. Operando Characterization of Iron Phthalocyanine Deactivation during Oxygen Reduction Reaction Using Electrochemical Tip-Enhanced Raman Spectroscopy. J. Am. Chem. Soc. 2019, 141, 15684-15692.

(15) Baranton, S.; Coutanceau, C.; Roux, C.; Hahn, F.; Léger, J. M. Oxygen reduction reaction in acid medium at iron phthalocyanine dispersed on high surface area carbon substrate: tolerance to methanol, stability and kinetics. J. Electroanal. Chem. 2005, 577, 223-234.

(16) Bonnett, R. 9.22 - Metal Complexes for Photodynamic Therapy. Comprehensive Coordination Chemistry II 2003, 945-1003.

(17) Moriya, M.; Takahama, R.; Kamoi, K.; Ohyama, J.; Kawashima, S.; Kojima, R.; Okada, M.; Hayakawa, T.; Nabae, Y. FourteenMembered Macrocyclic Fe Complexes Inspired by FeN4-CenterEmbedded Graphene for Oxygen Reduction Catalysis. J. Phys. Chem. C 2020, 124, 20730-20735.

(18) Marshall-Roth, T.; Libretto, N. J.; Wrobel, A. T.; Anderton, K. J.; Pegis, M. L.; Ricke, N. D.; Voorhis, T. V.; Miller, J. T.; Surendranath, Y. A pyridinic Fe-N4 macrocycle models the active sites in Fe/N-doped carbon electrocatalysts. Nat. Commun. 2020, 11, 5283.

(19) Nabae, Y.; Yuan, Q.; Nagata, S.; Kusaba, K.; Aoki, T.; Takao, N.; Itoh, T.; Arao, M.; Imai, H.; Higashi, K.; Sakata, T.; Uruga, T.; Iwasawa, Y. In Situ X-ray Absorption Spectroscopy to Monitor the Degradation of $\mathrm{Fe} / \mathrm{N} / \mathrm{C}$ Cathode Catalyst in Proton Exchange Membrane Fuel Cells. J. Electrochem. Soc. 2021, 168, 014513.

(20) Choi, C. H.; Baldizzone, C.; Grote, J.-P.; Schuppert, A. K.; Jaouen, F.; Mayrhofer, K. J. J. Stability of Fe-N-C Catalysts in Acidic Medium Studied by Operando Spectroscopy. Angew. Chem., Int. Ed. 2015, 54, 12753-12757.

(21) Singh, H.; Zhuang, S.; Ingis, B.; Nunna, B. B.; Lee, E. S. Carbon-based catalysts for oxygen reduction reaction: A review on degradation mechanisms. Carbon 2019, 151, 160-174.

(22) Chenitz, R.; Kramm, U. I.; Lefêvre, M.; Glibin, V.; Zhang, G.; Sun, S.; Dodelet, J.-P. A specific demetalation of Fe-N4 catalytic sites in the micropores of NC_Ar $+\mathrm{NH} 3$ is at the origin of the initial activity loss of the highly active $\mathrm{Fe} / \mathrm{N} / \mathrm{C}$ catalyst used for the reduction of oxygen in PEM fuel cells. Energy Environ. Sci. 2018, 11, $365-382$.

(23) Santori, P. G.; Speck, F. D.; Li, J.; Zitolo, A.; Jia, Q.; Mukerjee, S.; Cherevko, S.; Jaouen, F. Effect of Pyrolysis Atmosphere and Electrolyte $\mathrm{pH}$ on the Oxygen Reduction Activity, Stability and Spectroscopic Signature of FeNx Moieties in Fe-N-C Catalysts. J. Electrochem. Soc. 2019, 166, F3311-F3320.

(24) Klemm, S. O.; Topalov, A. A.; Laska, C. A.; Mayrhofer, K. J. J. Coupling of a high throughput microelectrochemical cell with online multielemental trace analysis by ICP-MS. Electrochem. Commun. 2011, $13,1533-1535$.

(25) Ferrandon, M.; Wang, X.; Kropf, A. J.; Myers, D. J.; Wu, G.; Johnston, C. M.; Zelenay, P. Stability of iron species in heat-treated polyaniline-iron-carbon polymer electrolyte fuel cell cathode catalysts. Electrochim. Acta 2013, 110, 282-291.

(26) García, Á.; Pascual, L.; Ferrer, P.; Gianolio, D.; Held, G.; Grinter, D. C.; Peña, M. A.; Retuerto, M.; Rojas, S. Study of the evolution of $\mathrm{FeNxCy}$ and $\mathrm{Fe} 3 \mathrm{C}$ species in $\mathrm{Fe} / \mathrm{N} / \mathrm{C}$ catalysts during the oxygen reduction reaction in acid and alkaline electrolyte. J. Power Sources 2021, 490, 229487.

(27) Alsudairi, A.; Li, J.; Ramaswamy, N.; Mukerjee, S.; Abraham, K. M.; Jia, Q. Resolving the Iron Phthalocyanine Redox Transitions for ORR Catalysis in Aqueous Media. J. Phys. Chem. Lett. 2017, 8, 28812886.
(28) Li, J.; Alsudairi, A.; Ma, Z.-F.; Mukerjee, S.; Jia, Q. Asymmetric Volcano Trend in Oxygen Reduction Activity of Pt and Non-Pt Catalysts: In Situ Identification of the Site-Blocking Effect. J. Am. Chem. Soc. 2017, 139, 1384-1387.

(29) Malko, D.; Kucernak, A.; Lopes, T. In situ electrochemical quantification of active sites in $\mathrm{Fe}-\mathrm{N} / \mathrm{C}$ non-precious metal catalysts. Nat. Commun. 2016, 7, 13285.

(30) Yamamoto, T. Assignment of pre-edge peaks in K-edge x-ray absorption spectra of $3 \mathrm{~d}$ transition metal compounds: electric dipole or quadrupole? X-Ray Spectrom. 2008, 37, 572-584.

(31) Choi, C. H.; Lim, H.-K.; Chung, M. W.; Chon, G.; Ranjbar Sahraie, N.; Altin, A.; Sougrati, M.-T.; Stievano, L.; Oh, H. S.; Park, E. S.; Luo, F.; Strasser, P.; Dražić, G.; Mayrhofer, K. J. J.; Kim, H.; Jaouen, F. The Achilles' heel of iron-based catalysts during oxygen reduction in an acidic medium. Energy Environ. Sci. 2018, 11, 31763182.

(32) Ohyama, J.; Okubo, K.; Ishikawa, K.; Saida, T.; Yamamoto, Y.; Arai, S.; Satsuma, A. Removal of Surface Poisoning Improves Hydrogen Oxidation Performance of $\mathrm{Pt}$ Catalysts under Basic Conditions. ACS Appl. Energy Mater. 2020, 3, 1854-1859. 